\title{
Looped and Perforated Elbow Pipes in Northeast Texas
}

Jesse Todd

Unknown

Follow this and additional works at: https://scholarworks.sfasu.edu/ita

Part of the American Material Culture Commons, Archaeological Anthropology Commons, Environmental Studies Commons, Other American Studies Commons, Other Arts and Humanities Commons, Other History of Art, Architecture, and Archaeology Commons, and the United States History Commons

Tell us how this article helped you.

This Article is brought to you for free and open access by the Center for Regional Heritage Research at SFA ScholarWorks. It has been accepted for inclusion in Index of Texas Archaeology: Open Access Gray Literature from the Lone Star State by an authorized editor of SFA ScholarWorks. For more information, please contact cdsscholarworks@sfasu.edu. 


\section{Looped and Perforated Elbow Pipes in Northeast Texas}

Creative Commons License

(c) (i) (8)

This work is licensed under a Creative Commons Attribution-NonCommercial 4.0 International License 


\section{Looped AND Perforated Elbow Pipes in Northeast TeXas}

\section{Jesse Todd}

Todd (2010) presented a general chronology for the presence of aboriginal-manufactured clay elbow pipes in Northeast Texas Caddo sites. Most of the pipe types have an extensive range in time; however, this may be true for thong elbow pipes. This paper looks further at the time range for, and the variety, of thong pipes.

Jackson (1933:72-73) refers to elbow pipes that have a hole between the keel and the bowl as "thong pipes". A string appears to have been run through the holes. He refers to the two types of pipes as "handled" and "holed," but "I use the terms "looped" and "perforated."' Perino (1983:70) mentions that the perforation in the pipe's keel may have been so that a cord could be fastened to the stem, similar to some French and Native American micmac pipes.

\section{Looped}

The looped thong pipe has a large gap between the bowl and the strap (Figure 1) and have been found in Anderson (Gilmore 1973), Bowie (Jackson 1932), Upshur (Jackson 1933) and Wood (Jackson 1933). Gilmore (1974:Figure 82g) illustrates a loop from a thong pipe from the Ferguson site (41AN67). The Ferguson site dates to ca. A.D. 1480-1560 (Timothy K. Perttula, 2010, personal communication). Jackson (1932:12) discovered a looped thong pipe in midden deposit at the E. H. Moore's Plantation site (41BW2) in Bowie County. Jackson (1932:54) believes the site to have been occupied post A.D. 1541 based upon the discovery of an adult burial that contained two musket balls. According to Timothy K. Perttula (2011, personal communication), the E. H. Moores Plantation site probably was occupied from ca. A.D. 1500 into the late $17^{\text {th }}$ century.

\section{Looped Pipes Outside of Texas}

Loop pipes have been found in Arkansas. Moore (1909:98) portrays a loop pipe from the Kent site in Ouachita County, Arkansas. Jackson (1933:85) states that the loop pipe from the Kent site is identical to one from the E. H. Moores site in Bowie County, Texas. According to Morse and Morse (1998), the Kent site dates to the Middle and Late Mississippian periods, which range from ca. A.D. 1350 to 1650. However, historic material was recovered from the Kent site (Morse and Morse 1998:298), suggesting it may date to the latter part of the time frame. Hodges and Hodges (1945:109) mention that loop pipes appear to be associated with the Mid-Ouachita phase Caddoaboriginal inhabitants of Arkansas. At one point, they mention that the loop pipe appeared to be an exclusive product of the Mid-Ouachita aboriginal inhabitants.

Excavations at the Poole site (3GA3) in Garland County, Arkansas recovered loop pipes (Wood 1981). One half of a Friendship Engraved bowl was associated with a burial containing the loop pipe. Early (2002:12) places Friendship Engraved pottery within the Mid-Ouachita phase, dating from A.D. 1400 to 1500. 


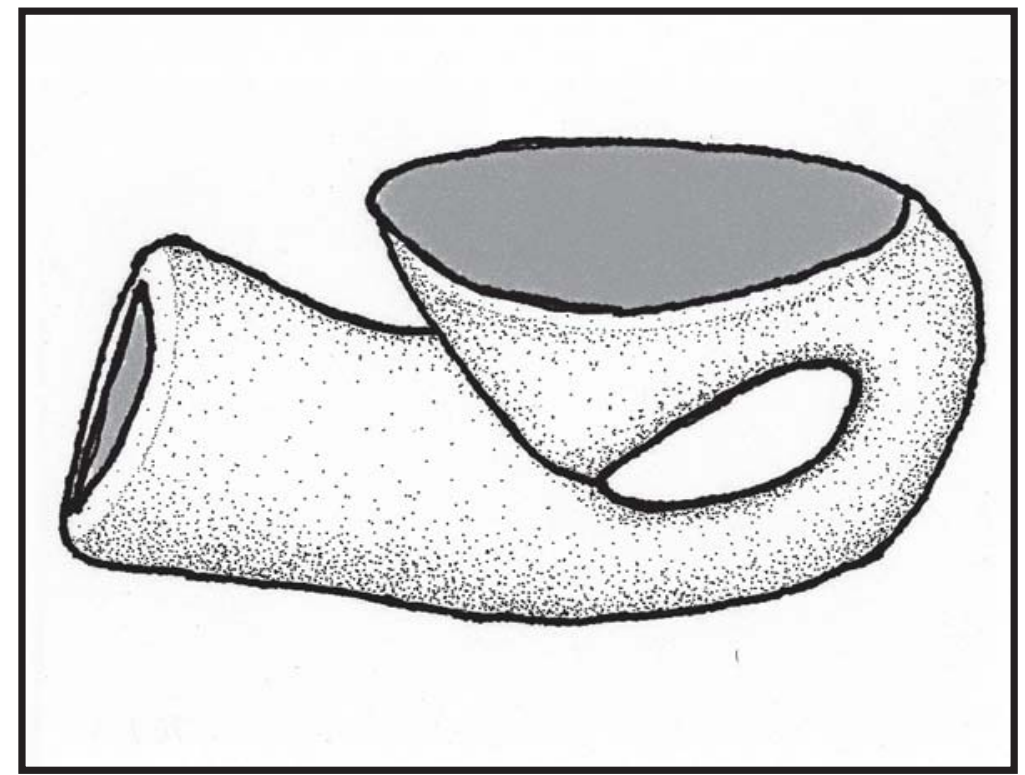

Figure 1. Loop pipe from Wood County (Jackson 1933:Plate 16). Redrawn by Lance K. Trask and reproduced with the permission of the Texas Archeological Society.

\section{Perforated}

The perforated thong pipe has a small perforation near its base (Figure 2). Examples have been discovered in Bowie (Gilmore 1986), Fannin (Harris 1953), Franklin (Jackson 1933), Lamar (Harris 1953; Wilson 1948) and Red River (Perino 1983). Gilmore (1986:168) illustrates two pipe fragments with perforations from the Rosebrough site (41BW5) in Bowie County. One pipe has a flat base. Miroir et al. (1973:163) date the Roseborough site between 1719 and 1778, but Gilmore (1986:33) states the site was occupied after the 1740s. A thong pipe was recovered from a burial from the Bob Williams site (41RR16) which contained an iron strike-a-lite, indicating that the pipe was used at a time of Caddo trade with Europeans. (Perino 1983:35, 70). Interestingly, the pipe from the Sanders site in Lamar County illustrated by Wilson (1948) is very similar to the one illustrated by Jackson (1933) from Franklin County shown in Figure 2.

Perttula (1993:153) mentions that burials containing European trade beads are present along Bois d'Arc Creek south of the major Middle Caddo period mound center at the Sanders site (41LR2) in Lamar County. Harris (1953:20) discovered an unusual perforated pipe shown in Figure 3 in this area. Instead of the perforation running perpendicular to the pipe as shown in Figure 2, the perforation runs through the center of the pipe bowl. Several trade beads, including blue and white beads, were found in the vicinity of the pipe and trade beads were found in two burials south of the mound and above the location where the pipe was found. 


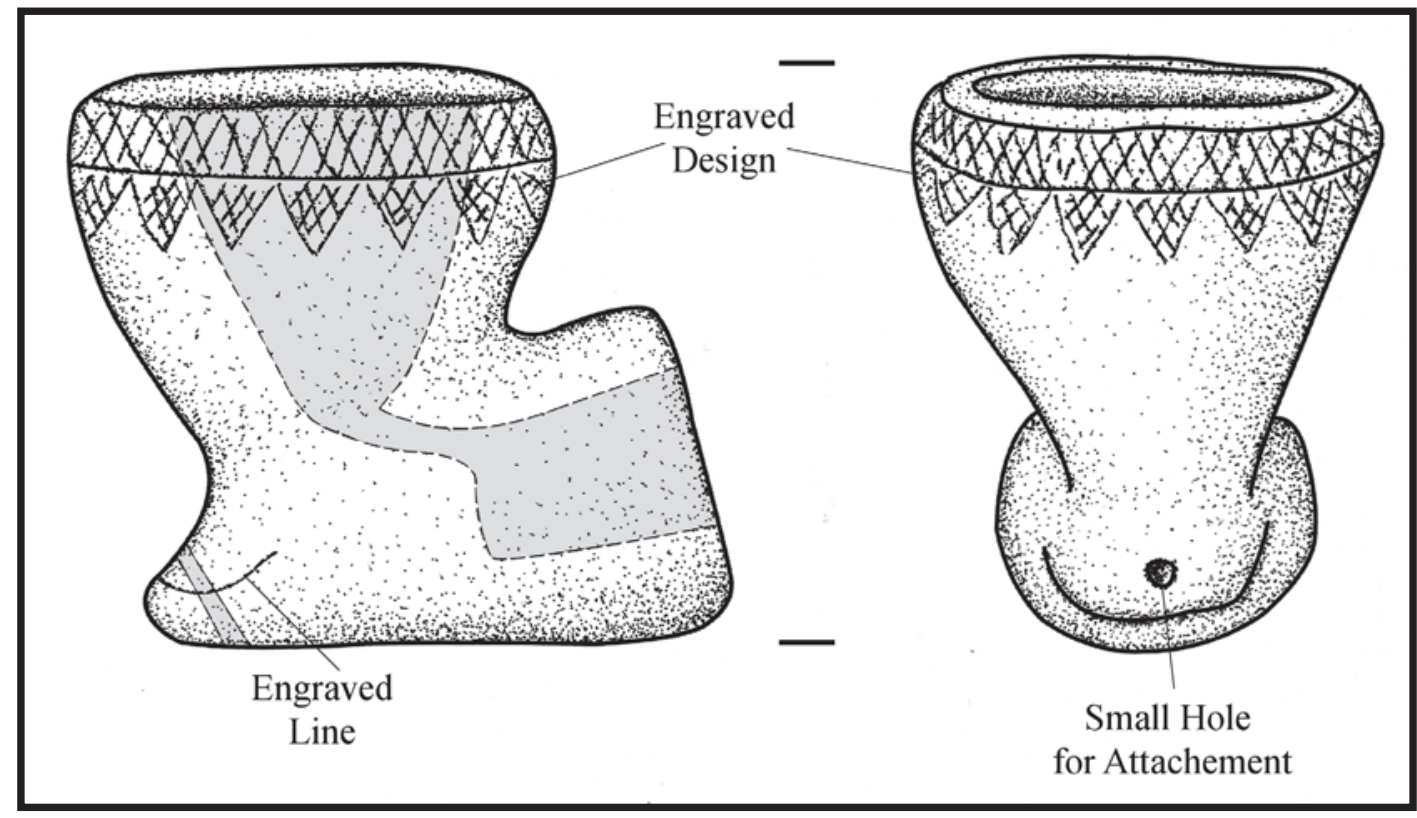

Figure 2. Perforated pipe from Franklin County (Jackson 1933:Plate 17). Redrawn by Lance K. Trask and reproduced with the permission of the Texas Archeological Society.

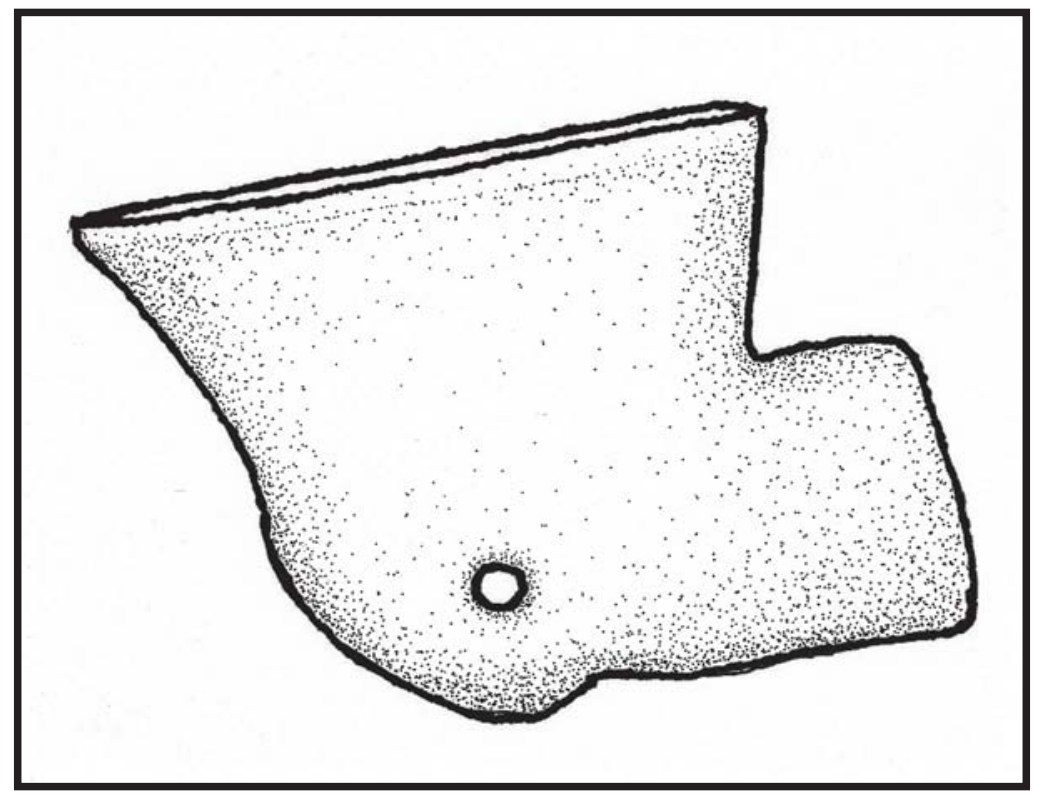

Figure 3. Perforated pipe from the Sanders site. Redrawn by Lance K. Trask and reproduced with the permission of the Dallas Archeological Society.

\section{Conclusions}

Although only a few thong pipes have been found in Northeast Texas, the pipes seem to be present during Late Caddo to Historic Caddo times (ca. A.D. 1500 to the late 1700s) which may indicate that Perino was correct in his supposition that perforated pipes were copies of European and Indian micmac pipes. 


\section{References Cited}

Early, Ann M.

2002 The Mid-Ouachita Phase. Field Notes (Newsletter of the Arkansas Archeological Society) 305:10-13.

Gilmore, Kathleen Kirk

1974 Analysis of Pipes. In Archaeological Investigations at Lake Palestine, by K. M. Anderson, K. Gilmore, O. F. McCormick, III and E. P. Morenon, pp. 192-197, Contributions in Anthropology No. 11, Department of Anthropology, Institute for the Study of Earth and Man, Southern Methodist University, Dallas, Texas.

1986 French-Indian Interaction at an $18^{\text {th }}$ Century Frontier Post: The Rosebrough Lake Site, Bowie County, Texas. Contributions in Archaeology No. 3, Institute of Applied Sciences, North Texas State University, Denton.

Harris, R. K.

1953 Two Recent Trips to Sites in Fannin and Lamar Counties. The Record (Dallas Archeological Society) 11(5):19-20.

Hodges, T. L. and Mrs. Hodges

1945 Suggestion for Identification of Certain Mid-Ouachita Pottery as Cahinnio Caddo. Bulletin of the Texas Archeological and Paleontological Society 16:98-116.

Jackson, A. T.

1932 Exploration of a Burial Site on E. H. Moores Plantation in Bowie County, Texas. Manuscript on file with the Texas Archeological Research Laboratory, The University of Texas at Austin.

1933 Indian Pipes of East Texas. Bulletin of the Texas Archeological and Paleontological Society 5:69-86.

Miroir, M. P., R. K. Harris, J. C. Blaine and J. McVay, with contributions by D. C. Book, F. Gigainero, R. McVay, Joe B. Raffaelli and P. E. Schoen

1973 Bénard de la Harpe and the Nassonite Post. Bulletin of the Texas Archeological Society 44:113-168.

Moore, Clarence B.

1909 Antiquities of the Ouachita Valley. Journal of the Academy of Natural Sciences of Philadelphia XIV:1-170.

Morse, Dan F. and Phyllis A. Morse

1998 Archaeology of the Central Mississippi Valley. The University of Alabama Press, Tuscaloosa.

Perino, Gregory

1983 Archaeological Research at the Bob Williams Site (41RR16), Red River County, Texas. Potsherd Press, Museum of the Red River, Idabel, Oklahoma. 
Perttula, Timothy K.

1993 Effects of European Contact on Native and Immigrant Indians in Northeast Texas. In Archeology in the Eastern Planning Region, Texas: A Planning Document. Edited by N. Kenmotsu and T. Perttula, pp. 147-190, Cultural Resources Management Report 3, Department of Antiquities Protection, Texas Historical Commission, Austin.

Todd, Jesse

2010 A Preliminary Classification of Clay Elbow Pipes from Northeast Texas. $52^{\text {nd }}$ Annual Caddo Conference and $17^{\text {th }}$ Annual East Texas Archeological Conference, Tyler, March 18-20, 2010.

Wilson, Lester

1948 Two Small Pipes from the Saunders Site near Direct. The Record (Dallas Archeological Society) 6(7):30.

Wood, Raymond W.

1981 The Poole Site, 3GA3. With New Forward and Summary by Ann M. Early. The Arkansas Archeologist 22:5-62. 